\title{
Thyroid Function Control among Pregnant Women Following a Therapeutic Thyroidectomy
}

\author{
Gilad Horowitz ${ }^{1}$, Maya Ish-Shalom ${ }^{2}$, Anton Warshavsky ${ }^{2}$, Naftali Stern ${ }^{2}$, Dan Fliss ${ }^{1}$, \\ Doron Comaneshter ${ }^{3}$, and Shlomo Vinker ${ }^{4}$ \\ ${ }^{1}$ Tel Aviv Sourasky Medical Center \\ ${ }^{2}$ Tel Aviv Ichilov-Sourasky Medical Center \\ ${ }^{3}$ Clalit Health Services \\ ${ }^{4}$ Tel Aviv University Sackler Faculty of Medicine
}

April 27, 2020

\begin{abstract}
Background: The total number of thyroidectomies performed worldwide both for benign and malignant disease has increased dramatically during the past few decades. Gestational hypothyroidism has deleterious effects on the fetus. Objective: The aim of this study was to assess the extent of thyroid function control among pregnant women who had previously undergone a therapeutic thyroidectomy. Methods: This retrospective cohort study included all female patients insured in the largest health maintenance organization in Israel who were pregnant between May, 2001 and September, 2012 and had a medical history of thyroid surgery. The thyroid-stimulating hormone (TSH) levels throughout the pregnancy were compared to recommended trimestral values. A multivariate analysis was performed to determine risk factors for not attaining TSH recommended range. Results: A total of 477 females with a history of thyroid surgery had given 701 births during the study period. Forty-three percent $(n=203)$, had thyroidal malignancy. Nearly half of the women underwent total thyroidectomy $(43.4 \% n=207)$. The women's TSH values were within the recommended range in only $60 \%(\mathrm{n}=350)$ of the pregnancies during the first trimester $(0.1-2.5 \mathrm{mIU} / \mathrm{L})$, in $61 \%(\mathrm{n}=335)$ during the second trimester $(0.2-3 \mathrm{mIU} / \mathrm{L})$, and in $70 \%(\mathrm{n}=338)$ during the third trimester (0.3-3 mIU/L). In multivariate analysis, women that underwent a total thyroidectomy due to a benign thyroid disease, were at the highest risk for not attaining target TSH levels. Conclusions: This very large cohort of pregnant women with a past history of thyroid surgery demonstrated a significant percentage of pregnancies with TSH values above the recommended range. Women that underwent a total thyroidectomy due to benign thyroid disease were at the highest risk for gestational hypothyroidism.
\end{abstract}

\section{Hosted file}

Pregnant Women Post-Thyroidectomy blinded.doc available at https://authorea.com/users/309382/ articles/445772-thyroid-function-control-among-pregnant-women-following-a-therapeutic-thyroidectomy

\section{Hosted file}

Table 1.docx available at https://authorea.com/users/309382/articles/445772-thyroid-functioncontrol-among-pregnant-women-following-a-therapeutic-thyroidectomy

\section{Hosted file}

Table 2.docx available at https://authorea.com/users/309382/articles/445772-thyroid-functioncontrol-among-pregnant-women-following-a-therapeutic-thyroidectomy

\section{Hosted file}


Table 3.docx available at https://authorea.com/users/309382/articles/445772-thyroid-functioncontrol-among-pregnant-women-following-a-therapeutic-thyroidectomy

\section{Hosted file}

Table 4.docx available at https://authorea.com/users/309382/articles/445772-thyroid-functioncontrol-among-pregnant-women-following-a-therapeutic-thyroidectomy

\section{Hosted file}

Table 5.docx available at https://authorea.com/users/309382/articles/445772-thyroid-functioncontrol-among-pregnant-women-following-a-therapeutic-thyroidectomy

\section{Hosted file}

Table 6.docx available at https://authorea.com/users/309382/articles/445772-thyroid-functioncontrol-among-pregnant-women-following-a-therapeutic-thyroidectomy

\section{Hosted file}

Table 7.docx available at https://authorea.com/users/309382/articles/445772-thyroid-functioncontrol-among-pregnant-women-following-a-therapeutic-thyroidectomy 